\title{
DETERMINATION OF INTERNAL FRICTION OF POLYMER SOLIDS WITH THE PULSE PROPAGATION TECHNIQUE
}

\author{
By Takayuki Murayama \\ (Monsanto Polymer Products Co. \\ 730 Worcester Street, Springfield, Mass. 01151)
}

\begin{abstract}
The pulse propagation technique has been useful to determine the dynamic Young's modulus of a wide range of materials. However, the applicability of the sonic technique to internal friction measurements on solids has not been exploited fully. In this report the theoretical and experimental studies on determination of internal friction of solids with the pulse propagation method are described. New instrumentation and a procedure for internal friction measurements are discussed.

The internal frictions are determined for the experimental polymer solids. Polyimid (PI), polyetherimide (Ultem), polyethersulfone (PES) and polyphenylene oxide show lower internal friction which indicates that polymers have stiff chain molecules in the structure and show high glass transition temperatures.

This method will be useful for non-destructive measurement of internal friction and opening new areas of application.
\end{abstract}

\section{INTRODUCTION}

The pulse propagation technique has been useful to determine the dynamic Young's modulus of a wide range of materials (e.g., metal rods ${ }^{1}$, concrete beams $^{2}$, paper $^{3)}$, composites $^{4}$, and fiber $^{5)}$ ). However, the applicability of the sonic technique to internal friction measurements on solids has not been exploited fully. In this report, the theoretical and experimental studies on determination of internal friction $(\tan \delta)$ of solids with the pulse propagation method are described. A new instrumentation and procedure of internal friction measurements are discussed.

\section{ANALYTICAL DEVELOPMENT}

In order to determine internal friction $(\tan \delta)$ of solids with the pulse propagation technique, the following mathematical analysis was carried out.

Dynamic modulus and dynamic compliance are complex quantities, considered to be composed of two parts which refer to the phase relationship between stress and strain. That part of the modulus wherein the stress, $\sigma$, and strain, $\varepsilon$, are in phase is called the storage modulus, $E^{\prime}$, or the real part of the complex modulus. That part of the modulus wherein the stress is in phase with the strain rate $\left(90^{\circ}\right.$ out of phase with the strain) is called the loss modulus, $E^{\prime \prime}$, or imaginary part of the complex modulus. Vector combination of the storage and loss moduli gives the complex modulus:

$$
\begin{aligned}
& E^{*}=E^{\prime}+i E^{*} \\
& \sigma=E^{*} \varepsilon
\end{aligned}
$$

Similar relationships exist for a complex compliance:

$$
\begin{aligned}
& J^{*}=J^{\prime}-i J^{\prime \prime} \\
& \varepsilon=J^{*} \sigma
\end{aligned}
$$

Pulse propagation methods are one of the many ways by which the dynamic modulus .can be measured. The storage and loss components are determined by the velocity of pulse propagation, $C$, and the attenuation per wave length, $2 \pi r$, respectively.

These two quantities, when measured, are used to calculate the two components of modulus through the equation ${ }^{6,7)}$; 


$$
\begin{aligned}
& E^{\prime}=\rho C^{2} \frac{1-r^{2}}{\left(1+r^{2}\right)^{2}} \\
& E^{\prime \prime}=2 \rho C^{2} \frac{r}{\left(1+r^{2}\right)^{2}}
\end{aligned}
$$

where $\rho$ is the sample density,

An alternative way of specifying the modulus is:

$$
E^{*}=E^{\prime}(1+i \tan \delta)
$$

where $\tan \delta=E^{\prime \prime} / E^{\prime}=2 r /\left(1-r^{2}\right)$

For most viscoelastic solids, at test temperatures other than at or near transition temperatures, $\tan \delta$ is .1 or less. $\quad r \ll 1$.

In these cases,

$$
r=\frac{1}{2} \tan \delta
$$

and the equations (5) and (6) can be simplified to

$$
\begin{aligned}
& E^{\prime}=\rho C^{3} \\
& E^{\prime \prime}=2 \rho C^{2} \gamma=\rho C^{2} \tan \delta \\
& E^{*}=\rho C^{2}(1+i \tan \delta)
\end{aligned}
$$

When the complex dynamic modulus is specified by equations (7) and (10), it is a function of the two parameters $C$ and $\tan \delta$. The pulse propagation instrument was primarily designed to measure the velocity of longitudinal mechanical pulses. However, recent modification in the instrument makes it possible to measure internal friction as well. The basis for this measurement is described as follows.

When mechanical pulses are propagated along rods of solids, they change in shape as a result of two separate causes. First, the lateral inertia of the rods results in dispersion, and secondly, the variation of mechanical properties of the material produces dispersion and attenuation of the pulse.

A theoretical investigation of the combined effects of the two types of dispersion would be of interest but would certainly involve complex mathematical analysis. When, however, the length of the pulse is large compared with the diameter of the rod, the effects of lateral inertia can be neglected and it has been shown that under these conditions the pulse shape can be accurately predicted from a knowledge of the variation of elastic modulus and damping with frequency.
Further, if the damping is sufficiently small, the effects of damping and velocity changes can be combined into a single parameter and the results of pulse attenuation expressed in a non-dimensional form which applies to all such viscoelastic solids. The single parameter is an operational equation in consideration of experimental technique.

The single parameter is $(d / c \tan \delta)$ where $d$ is the transducer separation (in centimeters), $c$ is the velocity of propagation (in centimeters per second), and $\tan \delta$ is the internal friction. The units of the single parameter are the units of time (seconds), and hence this quantity relates to the spreading in time of a pulse as it progresses along the length of the test sample. Examples of this are shown in Figures 3, 4, and 5. Data obtained from Figures 3, 4, and 5 are shown in Figure 6, where the width, $W$, in time (seconds) of the first halfwave of the received pulse is plotted against the path length (transducer separation). If the time function is considered to be equivalent to the single parameter $(d / c \tan \delta)$, the slope of the lines in Figure 6 will equal $(\tan \delta / C)$. The pulse velocity $c$ is measured with the pulse propagation meter. Thus, the internal friction is determined by

$$
\tan \delta=\frac{W_{2}-W_{1}}{d_{2}-d_{1}} C
$$

In actual operation, the calculation of internal friction can be simplified even further. Since the pulse propagation meter measures transit time which is related to propagation velocity by

$$
t_{8}-t_{1}=\frac{d_{2}-d_{1}}{c}
$$

the internal friction becomes

$$
\tan \delta=\frac{W_{2}-W_{1}}{t_{2}-t_{1}}
$$

where $W$ is the pulse width, $t$ is the transit time for the pulse, and the subscripts refer to two path lengths.

By using equation (13) or (15), the internal friction can be obtained. These analyses conclude that the pulse propagation technique is not only useful to determine the sonic modulus but also the internal friction. The complex modulus also can be determined by the measurement of both pulse velocity and internal friction. 


\section{EXPERIMENTAL}

The pulse propagation instrument was used for experiments in the above analytical development. This instrument consists of pulse generator and transmitter, pulse receiver, timing circuit, Tektronix 561 oscilloscope, and pulse recording camera. The transducers with round piezoelectric crystals were mounted vertically on the arms of a frame. The flight times of the strain pulses, which were generated by the instrument and traveled over specified sample lengths, were measured on a Tektronix $561 \mathrm{~A}$ oscilloscope.

The block diagram of this instrument is shown in Figure 1. The pulse generator sends a high voltage spike pulse to the transmitting transducer (60 pulses per second) while the pulse-generator simultaneously sends a trigger pulse to the oscilloscope to begin the sweep. A longitudinal mechanical pulse is transmitted along the test specimen and excites the receiving transducer, at which time the receiving transducer wave form is amplified and displayed on the oscilloscope. The time base of the oscilloscope is then used to read the elapsed time between the start of the trace and the point where the transducer waveform begins as shown in Figure 2. The pulse transit time and the distance between transducers are factors in determining

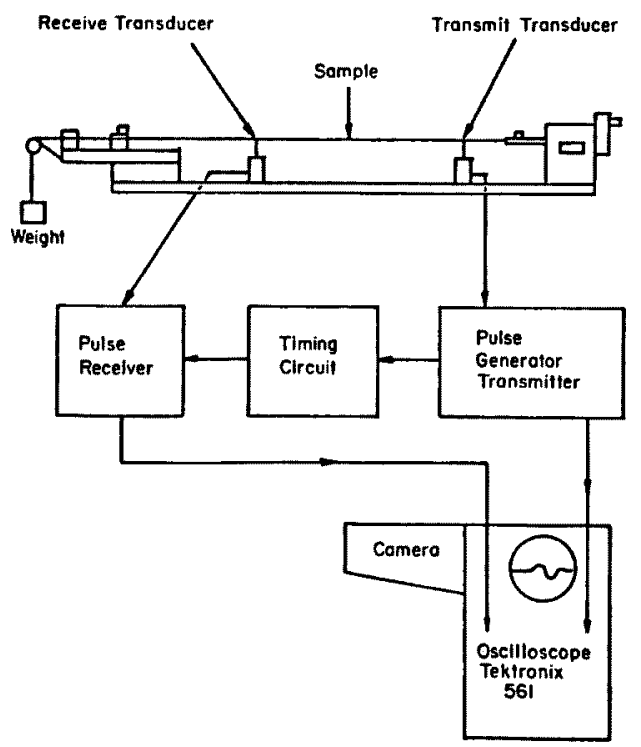

Fig. 1. Block diagram of pulse propagation apparatus
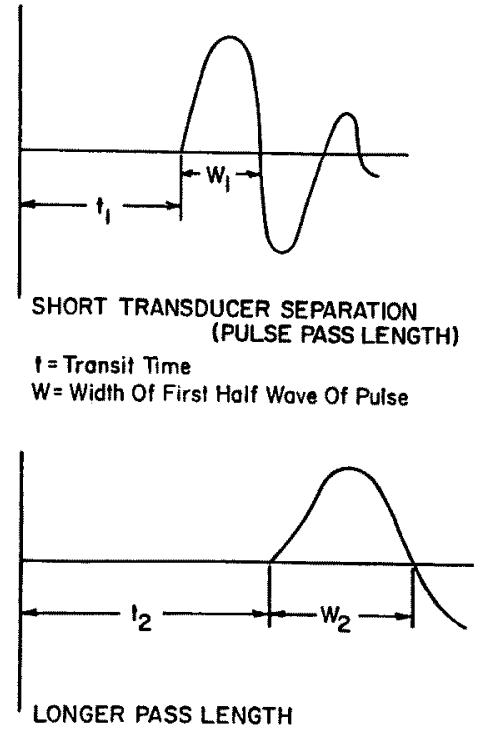

Fig. 2. Pulse wave form

sonic velocity. The width in time (seconds) of the first half-wave of the received pulse, as shown in Figure 2, is an important factor in determining the internal friction. The transducers are piezoelectric ceramics capable of operating over a wide temperature range. The pulse-generated displacement of the transmitting transducer is about $\mathbf{0 . 0 2 -}$ $0.05 \mathrm{~mm}$. Therefore, a very small strain amplitude is transmitted to the material at a frequency of around $15 \mathrm{KHZ}$.

\section{RESULTS AND DISCUSSION}

A number of experimental polymer solids, such as polyethersulfone (PES), brominated polyphenylene oxide (BrPPO), polyimid (PI) and polyetherimide (Ultem), nylon 66 and acrylic polymers have been examined for internal friction and acoustic modulus by using this technique.

These samples are rods or mono-filaments, round cross-section ( $500 \sim 800 \mu$, diameter). The densities of these materials are shown in Table I. In order to determine the internal friction of these materials, one of the most important measurements is accurate detection of the width in time (seconds) of the first half-wave of the received pulse ( $W_{2}$ and $\left.W_{1}\right)$ in two different pass lengths. Representative materials of these measurements are shown in Figures 3, 4, and 5. The two pass lengths (transducer separation) of the polymer solids are 
Table I. Internal friction and sonic modulus of experimental polymer solids (25 C, 65\% RH)

\begin{tabular}{lccccc}
\hline \multicolumn{1}{c}{ Samples } & $\begin{array}{c}\text { Sonic } \\
\text { velocity } \\
\mathrm{km} / \mathrm{sec}\end{array}$ & $\begin{array}{l}\text { Sonic } \\
\text { modulus } \\
\text { dynes/cm }\end{array}$ & $\begin{array}{l}\text { Internal } \\
\text { friction }\end{array}$ & $\begin{array}{c}\text { Density } \\
\mathrm{g} / \mathrm{cm}^{3}\end{array}$ & $\begin{array}{c}T_{\mathrm{g}} \\
{ }^{\circ} \mathrm{C}\end{array}$ \\
\hline Polyethersulfone (PES) & 1.06 & $1.54 \times 10^{10}$ & 0.016 & 1.45 & 196 \\
Polyimid (PI) & 1.13 & 1.81 & 0.018 & 1.60 & 235 \\
Polyetherimide (Ultem) & 1.78 & 3.96 & 0.015 & 1.24 & 185 \\
Polyphenylene oxide (BrPPO) & 1.20 & 1.53 & 0.012 & 1.28 & 210 \\
Cellulose acetate & 1.00 & 1.27 & 0.027 & 1.20 & 120 \\
Nylon 66 fiber & 2.17 & 5.17 & 0.10 & 1.14 & 65 \\
Acrylic fiber as spun & 3.33 & 12.0 & 0.082 & 1.20 & 104 \\
\hline
\end{tabular}

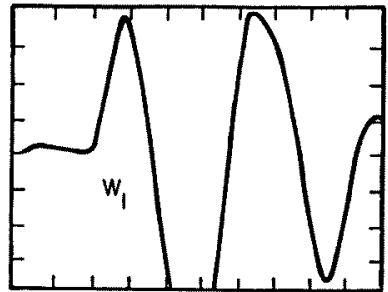

FIRST HALF WAVE OF PULSE, IN PASS LENGTH, $10 \mathrm{~cm}$, TIME SCALE, $50 \mu$ SEC/DIV

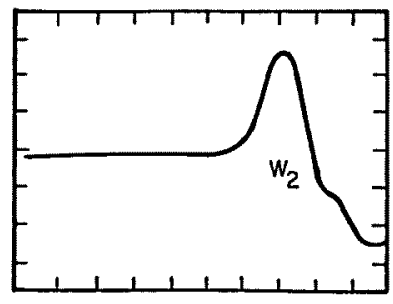

FIRST HALF WAVE OF PULSE IN PASS LENGTH, $30 \mathrm{~cm}$, TIME SCALE, $50 \mu$ SEC/DIV

Fig. 3. Polysolfone

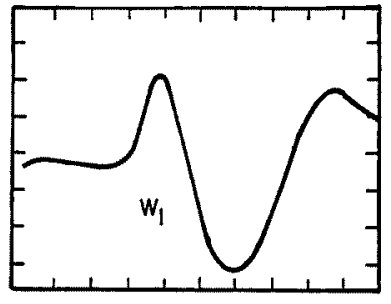

FIRST HALF WAVE OF PULSE, IN PASS LENGTH, $30 \mathrm{~cm}$, TIME SCALE, $50 \mu \mathrm{SEC} / D I V$

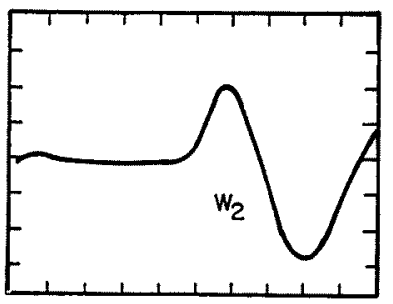

FIRST HALF WAVE OF PULSE, IN PASS LENGTH, $50 \mathrm{~cm}$, TIME SCALE $5 \mathrm{O}_{4} \mathrm{SEC} / \mathrm{DIV}$

Fig. 4. Nylon 66

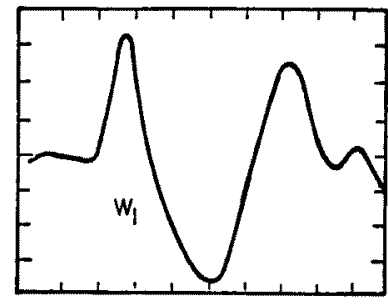

FIRST HALF WAVE OF PULSE, IN PASS LENGTH, $30 \mathrm{~cm}$, TIME SCALE,
$50 \mu$ SEC /DIV

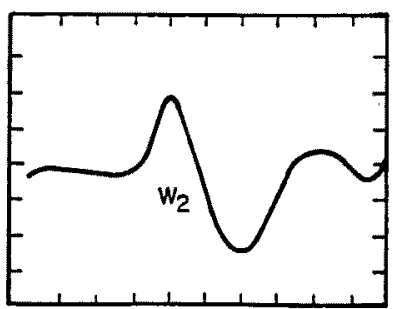

FIRST HALF WAVE OF PULSE, IN PASS LENGTH, $50 \mathrm{~cm}$, TIME SCALE $50 \mu$ SEC / DIV

Fig. 5. Acrylic polymer
10 and $30 \mathrm{~cm}$. However, in the case of nylon 66 and acrylic fiber, these pass lengths are 30 and $50 \mathrm{~cm}$.

The pass length against the width, $W$, in time of the first half-wave of the received pulse is plotted in Figure 6. The internal friction is determined from $W$ and the pass length, $d$, and acoustic velocity, $C$, by using equation (13). Table I shows these results of internal friction, sonic velocity and moduli on polymer solids.

The internal friction gives the amount of energy dissipated as heat during the deformation. It is also a good property index. If solid has a rigid molecular structure, the internal friction shows lower vahue.

As indicated in Table I, polyimid (PI), polyetherimide (Ultem), polyethyersulfone (PES), and brominated polyphenylene oxide (BrPPO) show lower internal friction. These polymers have stiff chain molecules in the structure and show high glass transition temperatures.

The determination of the internal friction of materials by using the pulse propagation technique is demonstrated for the first time. The width in time of the first half-wave of the pulse is related to the internal friction of materials. This method will be useful for non-destructive measurement of internal friction and opening new areas of appli- 


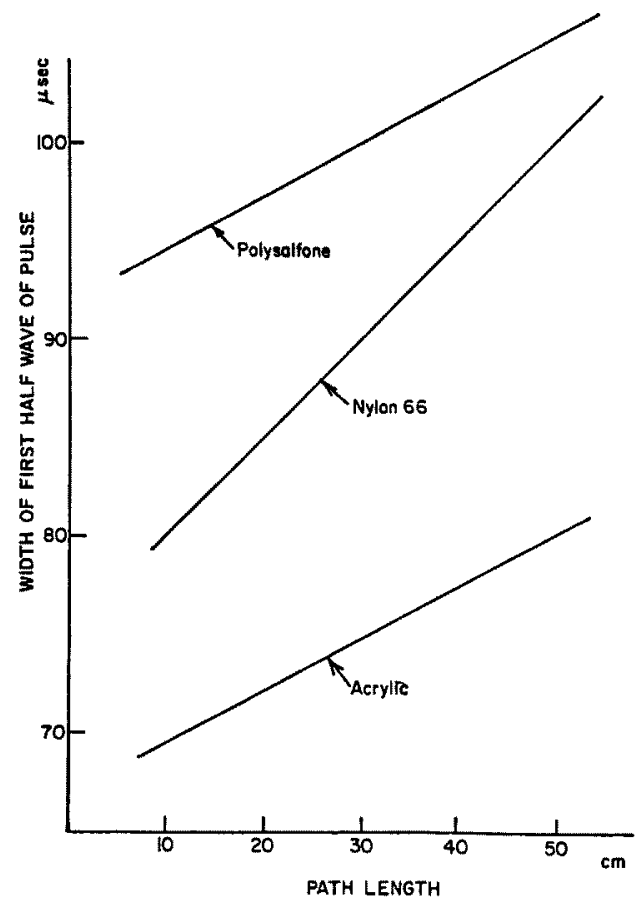

Fig. 6. Pulse path length vs width of half wave

cation.

\section{REFERENCES}

1) J. W. Rayleigh, "Theory of Sound," Dover Publications, New York, 1945 (Original Edition 1877).

2) R. C. McMaster, "Non-Destructive Testing Handbook," Ronald Press Company, New York, 1963, Sect. 43.9.

3) E. A. Whitehurst, "Evaluation of Concrete Properties from Sonic Tests," ACI Monograph No. 2, 1966, p. 3.

4) J. K. Craver and D. L. Taylor, "Non-Destructive Sonic Measurement of Paper Elasticity," Tappi, Plastic Conference, Oct. 198-21, 1964.

5) C. F. Zorowski and T. Murayama, "Wave Propagation and Dynamic Modulus in Continuous Filament Twisted Yarns," Tex. Res. J., 37, 852 (1967).

6) H. Kolsky, "Stress Waves in Solids," Dover Publication, Inc., New York, 1953.

7) T. Murayama, "Dynamic Mechanical Analysis of Polymeric Material," Elsevier, Amsterdam, 1978. 2nd Edition, 1982.

\section{波動伝播法による高分子固体の内部摩摖決定法}

$$
\text { モンサント株式会社 村山隆之 }
$$

波動伝播法は多くの材料の動的弾性率の決定に採用さ れている。しかし，乙の超音波法は固体の内部摩擦測定 には充分に利用されていない。

本法では，波動伝播法に上る固体の内部摩摖測定法の 理論と実験について述ぺた。新しい装置と測定方法につ いても討論を行った。
ポリイミド，ポリエーテルイミド，ポリエーテルサル ホン，ポリフェニレンオキサイドなどの内部摩擦は小さ い值であった。これは，てれらの高分子が剛直銷であり， 高いガラス転移温度をもつととを示している。この方法 は内部摩擦の非破壊測定法として有意義であり，新分野 への応用が期待される。 